\title{
PENERAPAN MODEL PEMBELAJARAN PENEMUAN TERBIMBING UNTUK MENINGKATKAN KEMAMPUAN SISWA KELAS VIIA SMP NEGERI 20 PALU DALAM MENEMUKAN RUMUS KELILING DAN LUAS DAERAH SEGITIGA
}

\author{
Zulfajri $^{1)}$, Anggraini ${ }^{2)}$, Gandung Sugita ${ }^{3)}$ \\ dzulfajrirustam@gmail.com ${ }^{1)}$,anggiplw67@gmail.com ${ }^{2)}$,gandungsugitapplw@gmail.com ${ }^{3)}$
}

\begin{abstract}
Abstrak: Penelitian ini bertujuan untuk mendeskripsikan tentang pelaksanaan model pembelajaran penemuan terbimbinguntuk meningkatkan kemampuan siswa kelas VII A SMP Negeri 20 Palu yang berlangsung dalam 2 siklus. Hasil penelitian menunjukkan bahwa pembelajaran dengan menerapkan model pembelajaran penemuan terbimbing dapat meningkatkan kemampuan siswa kelas VII A SMP Negeri 20 Palu dalam menemukan rumus keliling dan luas daerah segitiga dari siklus I ke siklus II dengan enam tahap yaitu : 1) stimulasi,2)perumusan masalah,3) pengumpulan data, 4) pemrosesan data, 5) verifikasi dan 6)generalisasi. Berdasarkan indikator keberhasilan, guru telahdapat menimbulkan ketertarikan siswa untuk menemukan rumus keliling dan luas daerah segitiga, serta dapat mengajukan pertanyaan yang membuat siswa membangun sendiri pengetahuannya berdasarkan teori konstruktivisme. Siswa juga telah mencapai indikator keberhasilannya yaitu siswa sudah saling membantu untuk menemukan rumus keliling dan luas daerah segitiga pada LKS. Selain itu, siswa sudah mampu menemukan sendiri rumus keliling dan luas daerah segitiga. Secara keseluruhan proses pembelajaran dengan menggunakan model penemuan terbimbing dapat mengaktifkan siswa serta membangun cara berpikirnya sendiri.
\end{abstract}

Kata kunci: penemuan terbimbing; peningkatan kemampuan; keliling segitiga; luas daerah segitiga

\begin{abstract}
This study aims to describe the implementation of guided discovery learning model to improve the ability of students of class VIIA SMP Negeri 20 Palu that wereconducted in 2 cycles. The result shows that learning process with the application of guided discovery learning could improve the students of class VIIA SMP Negeri 20 Palu abilities to find out the perimeter and surface area of triangle formulas from the first cycle to second cyclein six level, which were: 1) stimulation, 2) problem statement, 3) data collection, 4) data processing 5) verification, and 6) generalization. Based on success indicator, teacher had been able to attract students interestto find out the perimeter and surface area of triangle formulas, able to ask questions that helped students built their knowledge based on constructivism theory. In addition, students also had achieved success indicator in which they could help each other to findout the perimeter and surface area of triangle formulas on LKS. Moreover, students had been able tofind out the perimeter and surface area of triangle formulas. In overall, learning process by using guided discovery model couldmake students become more activealso build their own way of thinking.
\end{abstract}

Keywords: guided discovery, improved abilities, perimeter of triangle, surface area of triangle

Matematika merupakan ilmu yang berperan penting dalam kehidupan manusia. Pengetahuan matematika yang dimiliki seseorang sangat diperlukan untuk kehidupan seharihari maupun dalam menghadapi kemajuan ilmu pengetahuan dan teknologi. Karena itu matematika diajarkan kepada setiap peserta didik mulai dari jenjang sekolah dasar hingga ke perguruan tinggi. Matapelajaran matematika perlu diberikan kepada peserta didik untuk mengembangkan kemampuan berpikir logis, analitis, sistematis, kritis, dan kreatif mereka, serta kemampuan dalam bekerjasama (Megariati, 2011:2). Pada kurikulum 2013, geometri sebagai salah satu bidang kajian dalam materi matematika mendapatkan porsi yang paling besar (41\%) dibandingkan dengan materi lain seperti aljabar (29\%), bilangan (18\%), serta 
statistika dan peluang (12\%). Satu diantara materi geometri yang dipelajari siswa di tingkat SMP adalah keliling dan luas daerah segitiga.Menurut D. Agustine dan Smith (Sunardi, 2000: 36) pada dasarnya geometri mempunyai peluang besar untuk dimengerti anak dibandingkan dengan cabang matematika lainnya, karena benda-benda geometri dapat dijumpai anak-anak di lingkungannya, sehingga diharapkan siswa SMP juga tidak mengalami kesulitan pada materi segitiga, khususnya dalam menentukan keliling dan luas daerah segitiga. Akan tetapi, dari hasil penelitian yang dilakukan oleh Destiyandani, dkk (2016), diperoleh informasi bahwa siswa masih mengalami kesulitan dalam menyelesaikan masalah pada materi segitiga yang dibuktikan dengan rata-rata hasil Ulangan Tengah Semester 2 siswa yang masih rendah.

Fenomena tentang lemahnya pemahaman siswa pada materi geometri masih banyak dijumpai di sekolah, misalnya di kelas VIIA SMP Negeri 20 Palu. Hal ini disebabkan karena siswa hanya menghafal dan hanya ingin diberitahu oleh gurunya tentang rumus keliling dan luas daerah segitiga tanpa mempelajari langkah-langkah untuk menemukan rumus tersebut, sehingga itulah yang menyebabkan siswa pasif.

Menurut Rusmiati (2012) bahwa dengan menerapkan model penemuan terbimbing siswa diberikan kesempatan untuk menyelesaikan masalah kontekstual dengan cara mereka sendiri, sebelum diarahkan pada penyelesaian matematika formal.

Marzano (Markaban, 2008) mengemukakan kelebihan model pembelajaran penemuan terbimbing antara lain, (a) siswa dapat berpartisipasi aktif dalam pembelajaran yang disajikan, (b) menumbuhkan sekaligus menanamkan sikap inquiry (mencari-temukan), (c) mendukung kemampuan pemecahan masalah, (d) memberikan wahana interaksi antar siswa, maupun siswa dengan guru, dengan demikian siswa juga terlatih untuk menggunakan bahasa indonesia yang baik dan benar, dan (e) materi yang dipelajari dapat mencapai tingkat kemampuan yang tinggi dan lebih lama membekas karena siswa dilibatkan dalam proses menemukannya.

Sehubungan dengan hal yang diuraikan sebelumnya, dalam penelitian Nupita (2013) menunjukkan bahwa dengan menerapkan model penemuan terbimbing keterampilan pemecahan masalah dan hasil belajar siswa pada tiap-tiap siklus mengalami peningkatan. Selain itu, hasil yang diperoleh dari penelitian yang dilakukan oleh Rusmiati (2012) adalah model pembelajaran penemuan terbimbing dapat meningkatkan hasil belajar siswa pada materi geometri. Menyambung hal tersebut, penelitian yang dilakukan oleh Josephine (2010) dengan menggunakan model pembelajaran penemuan terbimbing juga dilakukan di Nigeria. Dalam tulisannya, Josephine (2010) menyarankan agar model pembelajaran penemuan terbimbing diadopsi di sekolah.

Berdasarkan penelitian-penelitian terdahulu tersebut dapat disimpulkan bahwa penerapan model pembelajaran penemuan terbimbing dalam pembelajaran matematika merupakan alternatif yang baik untuk dilakukan dalam proses pembelajaran.

\section{METODE PENELITIAN}

Jenis penelitian ini adalah penelitian tindakan kelas. Tahap pelaksanaan tindakan ini terdiri dari 2 siklus yang mengacu pada model penelitian tindakan kelas yang dikembangkan oleh Kemmis dan Mc. Taggart yang terdiri dari empat komponen yaitu perencanaan, pelaksanaan tindakan, observasi dan refleksi.Subjek penelitian adalah 3 orang siswa yang berkemampuan tinggi (SF), berkemampuan sedang (TS), dan berkemampuan rendah (AY) dari 25 orang siswa kelas VIIA SMP Negeri 20 Palu tahun ajaran 2017/2018. 
Data pada penelitian ini diperoleh dengan teknik observasi, wawancara, catatan lapangan, dan tes akhir tindakan. Data-data yang telah diperoleh tersebut dianalisis yang mengacu pada analisis data kualitatif menurut Miles, dkk (2014).

Tindakan penelitian dianggap berhasil apabila terjadi peningkatan aktivitas guru dan siswa berdasarkan indikator keberhasilannya serta peningkatan kemampuan siswa dalam menemukan rumus keliling segitiga pada siklus I, serta menemukan rumus luas daerah segitiga pada siklus II yang diperoleh dari tes akhir tindakan dan wawancara. Adapun indikator kebehasilan tindakan untuk aktivitas guru yaitu; (a) Dapat menimbulkan ketertarikan siswa untuk menemukan rumus keliling dan luas daerah segitiga, (b) Dapat mengajukan pertanyaan yang membuat siswa membangun sendiri pengetahuannya berdasarkan teori konstruktivisme, (c) Dapat membimbing siswa tanpa langsung memberikan generalisasi. Sedangkan indikator keberhasilan tindakan untuk aktivitas siswa yaitu; (a) Dapat membangun pengetahuannya sendiri dengan menjawab pertanyaan dari guru, (b) Bekerja sama dalam kelompok untuk menemukan rumus keliling dan luas daerah segitiga, (c) Mampu menemukan rumus keliling dan luas daerah segitiga secara mandiri dengan adanya tugas tambahan dan tes akhir tindakan.

Desain penelitian yang digunakan pada penelitian ini mengacu pada diagram yang dikembangkan oleh Kemmis dan Mc. Taggart (Arikunto, 2007:16). Desain ini menunjukkan bahwa pada setiap siklus dilakukan dengan 4 tahap yaitu planning (perencanaan), acting (tidakan), observing (pengamatan), dan reflecting (refleksi). Dalam pelaksanaannya, tahap acting dan observing dilakukan pada waktu yang sama, karena kedua tahap tersebut merupakan dua kegiatan yang tidak terpisahkan.

\section{HASIL PENELITIAN}

Hasil analisis tes awal menunjukkan bahwa hasil tes awal seluruh siswa sudah mecapai nilai ketuntasan minimal yaitu 70. Siswa sudah dapat menentukan keliling dan luas daerah persegi panjang serta mengetahui beberapa jenis segitiga yang dimaksud pada soal. Walaupun masih terdapat kesalahan antara lain kesalahan dalam menulis simbol sisi segitiga serta kesalahan dalam menentukan panjang sisi diagonal persegi panjang. Karena seluruh siswa sudah menguasai materi prasyarat, maka peneliti tidak perlu mengajarkan kembali materi prasyarat kepada siswa.

Kegiatan awal berlangsung selama 15 menit. Pada kegiatan tersebut, peneliti sebagai guru membuka pembelajaran dengan mengucapkan salam, meminta ketua kelas untuk memimpin teman sekelasnya berdoa bersama, mengecek kehadiran siswa, memberikan motivasi, memberitahukan tujuan pembelajaran, serta membagi siswa ke dalam 4 kelompok belajar. Pada siklus I, siswa yang hadir sebanyak 20 orang dan 5 orang siswa tidak hadir tanpa keterangan. Sedangkan pada siklus II, seluruh siswa hadir dalam mengikuti pembelajaran.

Kegiatan inti berlangsung selama 100 menit. Pada kegiatan tersebut dilaksanakan penerapan tahap-tahap model pembelajaran penemuan terbimbing sebagai berikut:

Tahap stimulasi siklus I dan siklus II yang dilakukan peneliti yaitu memberikan stimulus kepada siswa berupa masalah pada LKS bagian A sehingga timbul keinginan untuk mencari dan menyelesaikan sendiri masalah yang mereka hadapi. Hasil yang diperoleh pada siklus I ke siklus II mengalami peningkatan yaitu siswa lebih fokus dan tenang berdiskusi dengan teman kelompoknya mengenai LKS bagian A, serta pertanyaan yang mereka ajukan lebih terarah jika dibandingkan dengan siklus I. Hal ini dapat terbukti dari pertanyaan yang diajukan siswa pada siklus II mengenai LKS bagian A sebagai berikut:

Guru : Silahkan dibuka LKSnya, dan perhatikan LKS bagian A. Silahkan dibaca 
dulu dan diskusikan dengan teman kelompoknya. Bagaimana, ada yang mau ditanyakan untuk LKS bagian A?

Siswa : Langkah-langkahnya kita belum tahu kak.

Guru : Nah, bagaimana dengan yang lain?

Siswa : Iya kak, langkah-langkahnya belum tahu.

Guru : Baik, jadi pada pertemuan kali ini hampir sama juga dengan pertemuan minggu lalu. Tapi materi hari ini merupakan materi lanjutan dari pertemuan yang lalu, yaitu menemukan rumus luas daerah segitiga. Itulah yang akan kita lakukan pada hari ini, untuk menjawab pertanyaan pada LKS bagian A. Makanya kalian perhatikan baik-baik, tetap fokus belajar, supaya kalian bisa menjawab pertanyaan itu.

Siswa : Iya kak.

Tahap perumusan masalah pada siklus I dan siklus II yang dilakukan peneliti yaitu meminta siswa untuk mengidentifikasi masalah yang ada pada LKS bagian A kemudian menyampaikan hasil identifikasinya. Hasil yang diperoleh pada siklus II mengalami peningkatan dibandingkan dengan siklus I, yaitu siswa mulai mencoba menyampaikan rumusan masalah bersama teman kelompoknya, walaupun masih belum tepat. Adapun kutipan dialog tahap perumusan masalah pada siklus II tersebut adalah sebagai berikut:

Guru : Sudah dibaca LKS bagian A nya? Kalau sudah, coba satu orang sampaikan pendapatnya, apa yang ditanyakan pada LKS bagian A?

Siswa : Saya kak. Luas daerah segitiga.

Guru : Bagus. Ada pendapat lain?

Siswa : Saya kak. Langkah-langkah mencari luas daerah segitiga.

Guru : Bagus. Masih ada yang lain?

Siswa : (Diam)

Guru : Baik, jadi yang ditanyakan pada LKS bagian A itu, adalah bagaimana langkah-langkah menemukan rumus luas daerah segitiga. Jadi yang akan dicari itu langkah-langkah dalam menemukan rumusnya. Bisa difahami?

Siswa : Bisa kak.

Tahap pengumpulan dan pemrosesan data yang dilakukan peneliti yaitu meminta masing-masing kelompok mengamati LKS bagian B dan mengerjakan langkah-langkah yang ada pada LKS bagian B tersebut untuk menemukan rumus keliling segitiga pada siklus I, serta mengerjakan langkah-langkah untuk menemukan rumus luas daerah segitiga pada siklus II. Adapun hasil yang diperoleh pada tahap ini juga mengalami peningkatan dari siklus I ke siklus II, yaitu siswa lebih aktif bertanya tentang hal-hal yang mereka tidak faham sehingga proses pembelajaran menjadi lebih bermakna. Adapun pertanyaan siswa dapat dilihat pada kutipan dialog tahap pengumpulan dan pemrosesan data siklus II berikut:

Guru : Nah, sekarang lanjut ke LKS bagian B. Semuanya, perhatikan LKSnya.

Jadi sudah ada kertas berpetak dengan gambar segitiga yang sudah kakak sediakan. Sekarang silahkan kalian ikuti petunjuk yang ada pada LKS bagian $\mathrm{B}$ dan isilah titik-titik tersebut sesuai dengan hasil pekerjaan kalian bersama kelompok. Kalau ada yang ingin ditanyakan, silahkan bertanya.

Siswa : Kak, bagaimana menentukan tinggi segitiganya? 
Guru : Bagaimana yang lain, ada yang tahu bagaimana menentukan tinggi segitiga?

Siswa : Tidak tahu kak.

Guru : Baik, cara menentukan tinggi segitiganya itu dengan memisalkan salah satu sisi menjadi sisi alas, kemudian tarik garis melalui titik sudut yang berhadapan dengan sisi alas dan tegak lurus sisi alas tersebut.

Siswa : Oh, iya kak.

Siswa : Kak, yang di dalam tabel bagaimana?

Guru : Baik, jadi yang di dalam tabel juga dikerjakan yah, tapi kalian tidak perlu Melakukan percobaan membuat segitiga di kertas berpetak. Cukup kalian bayangkan saja, dengan cara yang sama seperti segitiga sebelumnya.

Siswa : Oh, iya kak.

Tahap verifikasi pada siklus I dan siklus II yang dilakukan peneliti yaitu memberikan tugas tambahan kepada setiap kelompok untuk mengukur kemampuan siswa dalam menemukan rumus keliling segitiga pada siklus I serta kemampuan siswa dalam menemukan rumus luas daerah segitiga pada siklus II, kemudian meminta siswa untuk menukarkan hasil pekerjaannya dengan kelompok lain yang telah ditentukan sebelumnya serta memeriksanya secara berkelompok. Hasil yang diperoleh pada siklus II juga mengalami peningkatan dari siklus I yaitu siswa lebih memperhatikan penyampaian dari kelompok yang memberikan tanggapan, dan suasana lebih tenang dibandingkan dengan siklus I. Hasil tugas tambahan setiap kelompok juga menunjukkan bahwa setiap kelompok telah mampu menemukan rumus luas daerah segitiga dengan benar, serta menggunakan langkah-langkah dengan tepat. Adapun kutipan dialog tahap verifikasi pada siklus II tersebut adalah sebagai berikut:

Guru : Sekarang, silahkan buka lembar terakhir, disitu ada tugas tambahan.

Silahkan kalian kerjakan tugas tambahan itu secara berkelompok, nanti kalau sudah selesai, masing-masing kelompok menukarkan hasil pekerjaannya seperti yang kita lakukan minggu lalu. Masih ingat yah?

Siswa : Iya kak.

Guru : Sudah selesai semua?

Siswa : Sudah kak.

Guru : Kalau begitu, sekarang tukarkan hasil pekerjaan kalian dengan kelompok yang lain, sama seperti sebelumnya. Selanjutnya, kalian diskusikan lagi jawaban kelompok lain yang ada sama kalian, kalau ada yang mau ditanggapi, silahkan.

Siswa : (Diam, memperhatikan pekerjaan kelompok lain)

Guru : Bagaimana, ada yang mau ditanggapi?

Siswa : Tidak ada kak.

Guru : Jawaban kalian bagaimana?

Siswa : Sama kak, Cuma beda hurufnya.

Guru : Oh, iya. Tidak apa-apa. Yang penting kalian sudah mengerti. Kalau cuma beda nama sisinya, tidak masalah. Berarti sudah benar semua yah.

Siswa : Iya kak. 
Tahap generalisasi pada siklus I dan siklus II yang dilakukan peneliti yaitu mengarahkan siswa untuk membuat kesimpulan dari pembelajaran yang telah dilakukan yaitu mengenai langkah-langkah dalam menemukan rumus keliling segitiga pada siklus I, serta menemukan rumus luas daerah segitiga pada siklus II. Hasil yang diperoleh pada siklus II yaitu kesimpulan yang dibuat oleh siswa mengalami peningkatan dari siklus I. Siswa menyimpulkan apa yang telah diperoleh dari kegiatan yang telah dilakukan dan menyebutkan bagaimana cara menemukan rumus luas daerah segitiga serta menyebutkan rumus yang ditemukan dengan benar. Hal ini membuktikan bahwa siswa mengalami kemajuan dalam menemukan rumus luas daerah segitiga. Peningkatan tersebut dapat ditunjukkan dengan kutipan dialog tahap generalisasi pada siklus II berikut:

Guru : Baik, sebelum kita menutup pembelajaran pada hari ini mari kita menyimpulkan hasil pembelajaran kita. Ayo, siapa yang mau menyimpulkan untuk pertemuan kali ini?

Siswa : (Diam)

Guru : Ayo, siapa yang bersedia menyimpulkan pembelajaran kita hari ini?

Yaitu bagaimana langkah-langkah menemukan rumus luas daerah segitiga. Pertama diapakan dulu?

Siswa : Saya kak. Pertama segitiganya diubah menjadi persegi panjang, kemudian dibandingkan luas segitiga dengan luas persegi panjang. panjang itu sama dengan alas segitiga, sedangkan lebarnya sama dengan setengah tinggi segitiga. Jadi didapat rumusnya, $\frac{1}{2} \times$ alas $\times$ tinggi.

Guru : Iya, bagus. Jadi dengan mengikuti langkah-langkah tersebut, diperoleh rumus luas daerah segitiga yaitu $\frac{1}{2} \times$ alas $\times$ tinggi. Bagaimana yang lain, sudah paham?

Siswa : Sudah kak.

Tes akhir tindakan pada siklus I terdiri dari 2 nomor. Satu diantara soal yang dikerjakan yaitu bagaimana langkah-langkah menemukan rumus keliling segitiga sama sisi. Hasil tes menunjukkan bahwa masih ada siswa yang melakukan kesalahan dalam menyelesaikan soal menemukan rumus keliling segitiga sama sisi ditunjukkan pada Gambar 2 berikut.

1. Segitiga Samo Susi
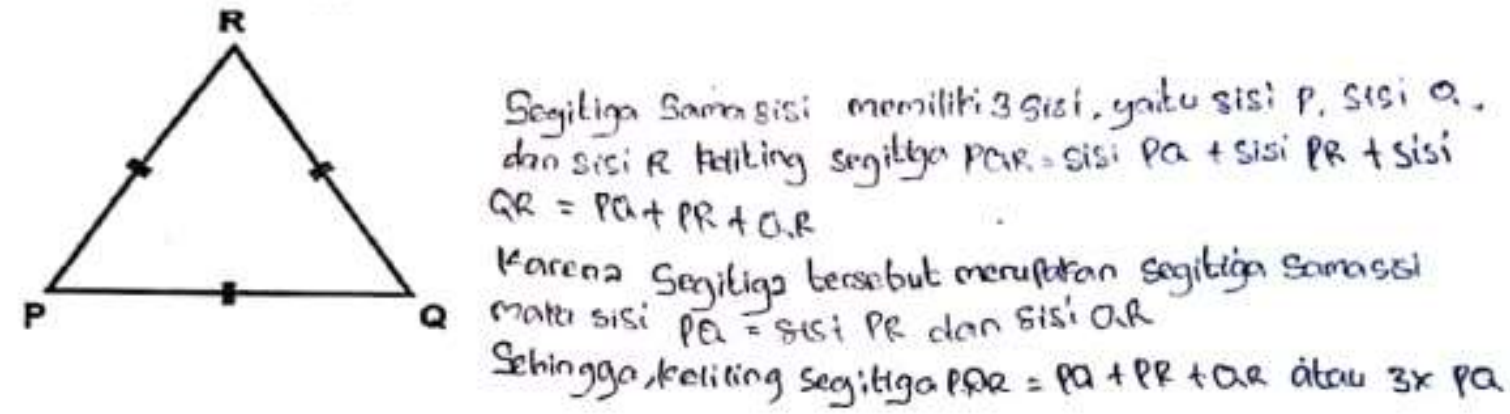

Gambar 2. Jawaban siswa SF pada Tes Akhir Tindakan Siklus I

Siswa SF sudah dapat menemukan rumus keliling segitiga pada soal nomor 1 (segitiga samasisi), namun dalam proses menemukan tersebut masih terdapat kesalahan 
penulisan seperti dalam menuliskan nama sisi-sisi segitiga. Siswa SF menuliskan sisi P, sisi $\mathrm{Q}$, dan sisi R. Sedangkan jawaban seharusnya adalah sisi PQ, sisi QR, dan sisi PR. Kesalahan yang sama juga terjadi subjek penelitian yang lain yaitu siswa TS dan AY. Adapun kutipan wawancara peneliti dengan siswa SF mengenai hasil tes akhir tindakan yang telah dikerjakan siswa SF adalah sebagai berikut:

SFS1 $03 \mathrm{P}$ : Oke, SF. Selanjutnya kita akan melakukan wawancara untuk hasil

Pekerjaan kamu di tes akhir tindakan siklus 1, yaitu menemukan keliling segitiga.

SFS1 $04 \mathrm{~S}$ : Iya kak.

SFS1 $05 \mathrm{P}$ : Nah, yang pertama. Kakak mau tanya, nomor 1 ini segitiga apa namanya?

SFS1 $06 \mathrm{~S}$ : Samasisi

SFS1 $07 \mathrm{P}$ : Kenapa disebut segitiga samasisi?

SFS1 $08 \mathrm{~S}$ : Karena memiliki tiga sisi yang sama.

SFS1 $09 \mathrm{P}$ : Oke, tiga sisi yang sama. Sisi apa semua yang sama?

SFS1 $10 \mathrm{~S}$ : Sisi P, sisi Q, sisi R.

SFS1 $11 \mathrm{P}$ : Nah, ini masih keliru yah. Harusnya bukan sisi P, sisi Q, sisi R. Tapi sisi PQ, sisi

SFS1 $12 \mathrm{~S}$ : Iya kak. QR, sisi PR. Lain kali diperhatikan lagi yah

Tes akhir tindakan siklus II terdiri atas 2 nomor soal. Berdasarkan hasil tes akhir tindakan siklus II terhadap subjek penelitian, diperoleh bahwa ketiga subjek mempunyai peningkatan dalam menemukan rumus luas daerah segitiga. Ketiga subjek penelitian (SF, TS, dan AY) telah mampu menemukan rumus luas daerah segitiga seperti yang diharapkan walaupun masih ada beberapa kekeliruan dalam penulisan. Adapun jawaban siswa AY pada tes akhir tindakan siklus II untuk soal nomor 1 dapat dilihat pada gambar berikut.

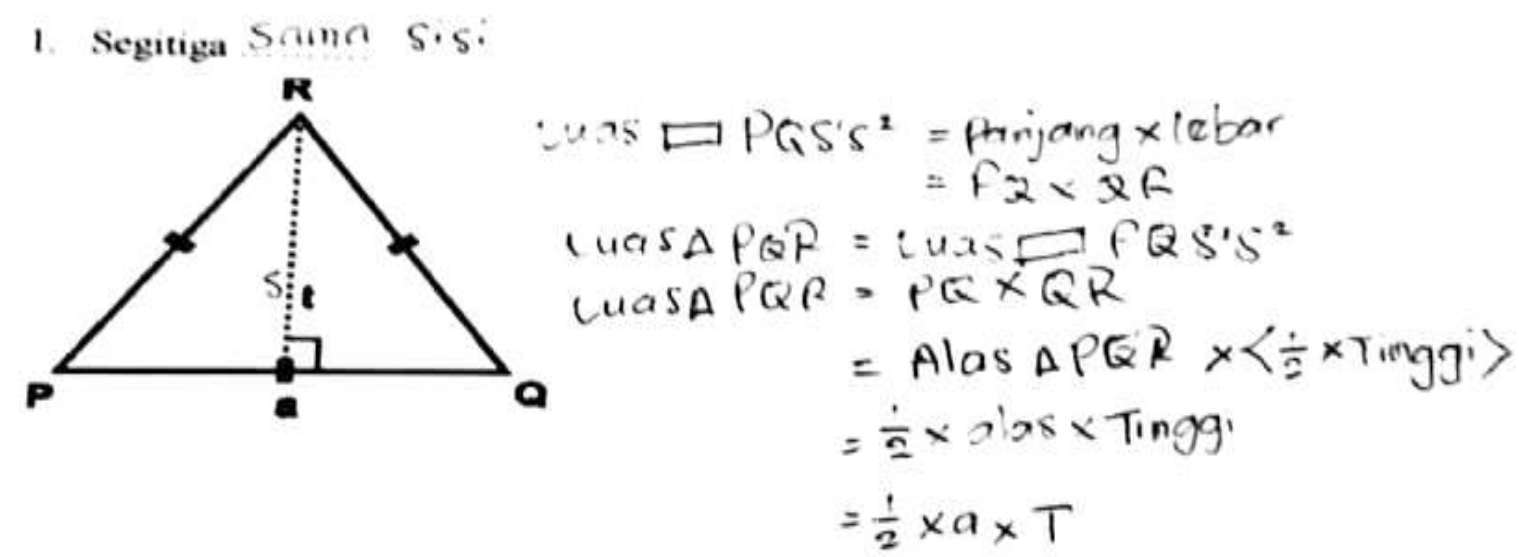

Gambar 3. Jawaban siswa AY pada Tes Akhir Tindakan Siklus II

Berdasarkan Gambar 3 tersebut, terlihat bahwa siswa AY telah mampu menemukan rumus luas daerah segitiga dengan benar, walaupun masih terdapat kesalahan penulisan yaitu siswa AY menuliskan panjang $\times$ lebar $=\mathrm{PQ} \times \mathrm{QR}$. Sedangkan jawaban seharusnya adalah $\mathrm{PQ}$ $\times$ QS karena segitiga tersebut telah diubah ke dalam bentuk persegi panjang. Adapun kutipan wawancara peneliti dengan siswa AY mengenai hasil tes akhir tindakan untuk soal nomor 1 yang telah dikerjakan siswa AY adalah sebagai berikut:

AYS2 03 P : Oke, AY. Jadi kita akan melakukan wawancara untuk siklus II ini.

Jadi kakak akan bertanya sama kamu tentang bagaimana

Menyelesaikan tes akhir tindakan dalam menemukan luas daerah 


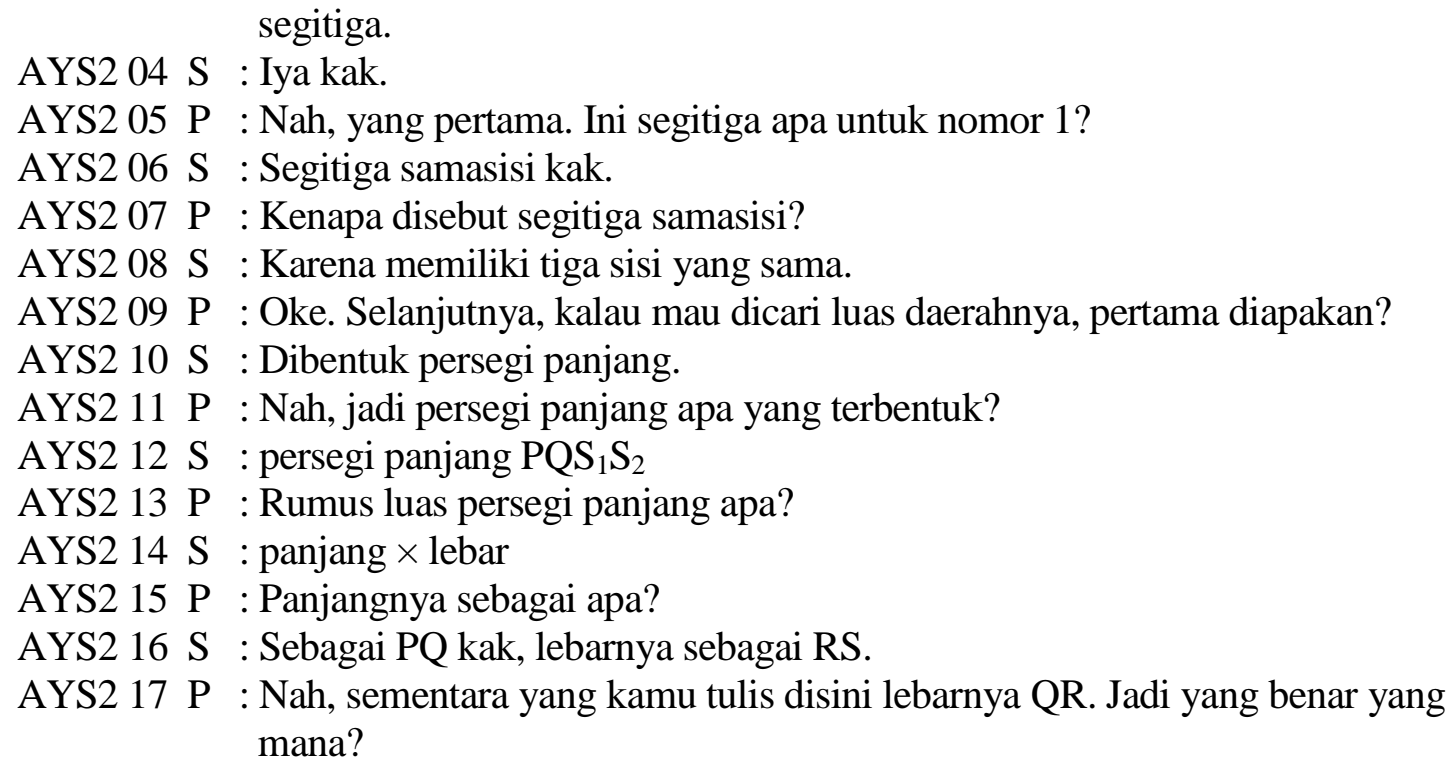

AYS2 18 S : yang RS kak, atau bisa ditulis QS juga

Hasil observasi aktivitas guru (peneliti) menunjukkan bahwa kemampuan peneliti sebagai guru dalam mengelola pembelajaran dengan menggunakan model pembelajaran penemuan terbimbing pada umumnya mengalami peningkatan. Menurut pengamat, peneliti telah mampu meningkatkan keterlibatan siswa dalam proses pembelajaran dan bantuan yang diberikan kepada siswa tidak berlebihan. Guru juga telah memenuhi indikator keberhasilannya yaitu dapat menimbulkan ketertarikan siswa untuk menemukan rumus luas daerah segitiga, serta dapat mengajukan pertanyaan yang membuat siswa membangun sendiri pengetahuannya berdasarkan teori konstruktivisme.

Selanjutnya, hasil observasi terhadap aktivitas siswa dalam mengikuti pembelajaran juga menunjukan adanya peningkatan. Menurut pengamat bahwa semangat belajar siswa sudah lebih bagus, siswa sudah berani bertanya baik kepada temannya maupun kepada guru (peneliti) serta siswa juga sudah saling membantu untuk menemukan rumus luas daerah segitigapada LKS meskipun masih ada kelompok yang kurang bekerja sama, namun secara keseluruhan proses pembelajaran dengan menggunakan model penemuan terbimbing dapat mengaktifkan siswa serta membangun cara berpikirnya sendiri. Selain itu, siswa sudah mampu menemukan sendiri rumus luas daerah segitiga yang terlihat dari hasil pekerjaan tugas tambahan sisa secara berkelompok.

Hal tersebut mengindikasikan bahwa keberhasilan tindakan telah tercapai pada siklus II karena telah mengalami peningkatan sesuai dengan kriteria keberhasilan tindakan, sehingga tidak perlu ada tindakan selanjutnya. Dengan demikian, dapat disimpulkan bahwa peneliti telah berhasil dan penelitian tindakan kelas yang dilakukan berakhir pada siklus II.

\section{PEMBAHASAN}

Hasil yang diperoleh dari tes awal menunjukkan bahwa seluruh siswa sudah mencapai nilai ketuntasan minimal yaitu 70 , walaupun masih terdapat beberapa kesalahan antara lain kesalahan dalam penulisan serta kesalahan dalam menentukan panjang sisi diagonal persegi panjang. Hal ini sesuai dengan pendapat Purwatiningsi (2013) yang menyatakan bahwa pemberian tes awal sebelum perlakuan dilakukan dengan memberikan informasi tentang kekeliruan siswa dalam menjawab pada materi prasyarat. Selain itu, hasil tes awal digunakan 
sebagai pertimbanganpembentukan kelompok belajar yang heterogen dan penentuansubjek penelitian.

Kegiatan awal pembelajaran dilakukan peneliti dengan mengucapkan salam, menyapa siswa, mengajak siswa untuk berdoa dan mengecek kehadiran siswa, serta mempersiapkan siswa untuk belajar. Mempersiapkan siswa untuk belajar memang perlu untuk dilakukan agar siswa siap dalam belajar baik merespon maupun menerima atau menolak materi yang diberikan. Hal ini sesuai dengan hukum kesiapan Gintings (2008) yang menjelaskan tentang adanya hubungan antara kesiapan seseorang dalam merespon, menerima atau menolak terhadap stimulan yang diberikan.

Selanjutnya, peneliti memberikan apersepsi kepada siswa tentang pembelajaran sebelumnya. Sejalan dengan pendapat Rohani (2004) bahwa apersepsi disajikan melalui pertanyaan untuk mengetahui apakah siswa masih ingat atau lupa, sudah menguasai atau belum tentang suatu materi dan hasilnya dijadikan acuan untuk memulai pengajaran yang baru.

Kemudian peneliti menyampaikan tujuan pembelajaran yang ingin dicapai yaitu untuk rumus keliling dan luas daerah segitiga dan memberikan motivasi kepada siswa sehingga siswa bersemangat dalam mengikuti pembelajaran. Hal ini sesuai dengan pendapat Barlian (2013) yang menyatakan bahwa penyampaian tujuan pembelajaran dilakukan agar siswa mengetahui dan berusaha mencapai tujuan pembelajaran yang diinginkan.

Sebelum melakukan tahap stimulasi, peneliti terlebih dahulu membagi siswa ke dalam kelompok yang heterogen yang terdiri dari 5 orang siswa. Pembentukan kelompok yang dilakukan peneliti mempunyai tujuan yaitu agar guru tidak kesulitan untuk membimbing siswa serta siswa dapat bekerja sama dalam mengatasi kesulitan selama proses pembelajaran. Hal ini didukung oleh Winayawati, dkk (2012) yang menyatakan bahwa saat pembentukan kelompok guru mengelompokkan siswa dengan tingkat kemampuan yang berbeda ke dalam kelompok kecil yang terdiri dari empat sampai enam orang siswa.

Tahap stimulasi dilakukan peneliti dengan memberikan stimulus kepada siswa berupa masalah yang ada pada LKS bagian A sehingga siswa merasa ingin mencari tahu bagaimana cara untuk menyelesaikan masalah tersebut yaitu menemukan rumus keliling dan luas daerah segitiga. Hal tersebut sesuai dengan pendapat Syah (Hosnan,2014) bahwa siswa harus dihadapkan pada sesuatu yang menimbulkan kebingungannya agar timbul keinginan mencari untuk menyelidiki sendiri. Hal tersebut juga diterapkan pada tahap perumusan masalah yaitu peneliti meminta siswa untuk mengidentifikasi masalah yang disajikan, menampung masalah tersebut, dan menegaskan masalah yang sebenarnya.

Tahap pengumpulan dan pemrosesan data dilakukan peneliti dengan berkeliling selama siswa mengerjakan LKS. Ini dilakukan agar setiap siswa yang bermasalah dalam menyelesaikan LKS dapat secepatnya diberikan bimbingan. Hal ini sesuai dengan pendapat Nusantara dan Syafi'i (2013) yang menyatakan bahwa seorang guru memiliki kewajiban dalam mengatasi kesulitan yang dialami siswa pada proses belajarnya dengan melakukan upaya pemberian bantuan seminimal mungkin dikenal dengan istilah scaffolding.

Tahap verifikasi dilakukan peneliti dengan mengarahkan siswa setiap kelompok untuk saling menukarkan dan memeriksa hasil pengerjaan tugas tambahan kelompok tukarnya serta menanggapi hasil pemeriksaannya. Hal ini sejalan dengan Rahmawati (2013) yang menyatakan perlunya pembiasaan untuk memberikan tanggapan terhadap jawaban yang diberikan orang lain dalam pembelajaran matematika, sehingga yang dipelajari siswa menjadi lebih bermakna. Peneliti bertindak sebagai fasilitator untuk mengontrol kerjasama siswa dan memberikan bimbingan yang bersifat terbatas kepada kelompok yang mengalami kesulitan. Hal ini, sesuai dengan pendapat Sari, dkk (2014) yang menyatakan bahwa guru bertindak sebagai fasilitator, 
membimbing siswa yang mengalami kesulitan dan bimbingan yang diberikan hanya sebagai petunjuk agar siswa bekerja lebih terarah.

Tahap generalisasi dilakukan peneliti dengan mengarahkan siswa untuk membuat kesimpulan sesuai dengan kegiatan pembelajaran yang telah dilakukan. Hal ini juga didukung oleh pendapat Barlian (2013) yang menyatakan bahwa guru bersama-sama dengan siswa membuat simpulan pelajaran pada akhir pembelajaran. Setelah itu pada kegiatan penutup, peneliti menginformasikan kegiatan pembelajaran yang akan dilakukan pada pertemuan berikutnya. Kemudian peneliti mengakhiri pembelajaran dengan mengucapkan salam

Hasil analisis akhir tindakan siklus I menunjukkan bahwa ketiga subjek penelitian telah mampu menemukan rumus keliling segitiga meskipun masih terdapat kesalahan penulisan yaitu dalam pemberian nama sisi-sisi segitiga atau kurang lengkap menuliskan langkah-langkah dalam menemukan rumus keliling segitiga. Namun, hasil analisis tes akhir tindakan siklus II mengalami peningkatan dari siklus I. Ketiga subjek penelitian telah berhasil menemukan rumus luas daerah segitiga dengan langkah-langkah yang sesuai dengan yang diaharapkan serta kesalahan penulisan yang lebih sedikit dibandingkan dengan hasil pada siklus I.

Setelah pembelajaran siklus I berakhir, peneliti melakukan refleksi terhadap seluruh kegiatan pembelajaran yang dilakukan. Refleksi ini dilakukan untuk mengetahui segala kekurangan yang terjadi pada pelaksanaan siklus I dan rekomendasi kegiatan perbaikan pada siklus II. Hal ini sesuai dengan pernyataan Arikunto (2007) bahwa refleksi adalah kegiatan menganalisis data yang telah diperoleh berdasarkan tes awal yang dilakukan sebelum kegiatan pembelajaran berlangsung, hasil tes akhir tindakan yang dilakukan sesudah tindakan pembelajaran, hasil observasi, catatan lapangan, dan hasil wawancara sebagai dasar perbaikan rencana siklus berikutnya.

Hasil observasi guru mengalami peningkatan dari siklus I ke siklus II yaitu guru sudah fokus kepada siswa, guru membimbing siswa seperlunya saja dengan teknik scaffolding, dan menurut pengamat guru sudah membimbing dan mengarahkan siswa dengan tenang. Guru juga telah memenuhi indikator keberhasilan guru. Hasil observasi siswa juga mengalami peningkatan dari siklus I ke siklus II yaitu pada awalnya siswa sudah antusias menjawab apersepsi yang diberikan guru tentang prisma. Siswa juga sudah tenang pada saat pembagian kelompok. Siswa juga memikirkan pemecahan masalah yang diberikan secara bersama-sama. Semua siswa dari yang berkemampuan tinggi, sedang, rendah turut andil dalam pemecahan masalah. selain itu, semua kelompok berhasil menemukan luas permukaan prisma. Hal ini sejalan dengan penelitian yang dilakukan oleh Sari dan Jatmiko (2014) yang mengemukakan bahwa aktivitas pada proses pembelajaran guided discovery siswa mengalami peningkatan, siswa lebih aktif dan lebih berani mengemukakan pendapatnya. Siswa juga telah memenuhi indikator keberhasilan siswa.

\section{KESIMPULAN}

Berdasarkan hasil penelitian dan pembahasan, maka dapat disimpulkan bahwapenerapan model pembelajaran penemuan terbimbing dapat meningkatkan kemampuan siswa kelas VII A SMP Negeri 20 Palu dalam menemukan rumus keliling dan luas daerah segitiga dengan mengikuti tahap-tahap model pembelajaran penemuan terbimbing, yaitu, (1) stimulasi yaitu siswa diberikan rangsangan berupa masalah yang ada pada LKS bagian A untukmenemukan rumus keliling dan luas daerah segitiga; (2)perumusan masalah yaitu siswa mengidentifikasi masalah yang disajikan pada LKS bagian A; (3) pengumpulan data yaitu yaitu siswa menghubungkan 3 batang lidi dengan berbagai ukuran yang telah disediakan dalam rangka menemukan rumus keliling segitiga, 
serta mengubah bangun segitiga menjadi bangun segiempat menggunakan alat peraga untuk menemukan rumus luas daerah segitiga; (4) pemrosesan data yaitu setiap kelompok mengamati LKS bagian B serta mendiskusikannya, kemudian mengerjakan langkahlangkah untuk menemukan rumus keliling dan luas daerah segitiga pada LKS bagian B; (5) verifikasi yaitu setiap kelompok yang telah mengerjakan LKS menukarkan hasil pekerjaannya dengan kelompok lainnya untuk membuktikan kebenaran rumus keliling dan luas daerah segitiga; (6) generalisasi yaitu siswa menyimpulkan tentang langkah-langkah menemukan rumus keliling dan luas daerah segitiga.

\section{SARAN}

1. Berdasarkan hasil penelitian yang telah dilaksanakan, maka beberapa saran yang dapat diberikan kepada guru dan peneliti selanjutnya, yaitu: (a) guru dapat mengimplementasikan model pembelajaran penemuan terbimbing sebagai salah satu alternatif pembelajaran matematika, (b) pembelajaran dengan implementasi model pembelajaran penemuan terbimbing dapat dikembangkan lagi sehingga selain dapat meningkatkan kemampuan siswa dalam menemukan rumus keliling dan luas daerah segitiga, juga dapat digunakan untuk meningkatkan kemampuan siswa dalam menggunakan rumus untuk menyelesaikan soal-soal yang terkait dengan keliling dan luas daerah segitiga, (c) pada tahap pemrosesan data, guru sebaiknya lebih fokus dalam mengamati kelompok/siswa yang perlu mendapat bimbingan, (d) dalam memberikan bimbingan, sebaiknya guru tidak berlebihann kepada siswa yaitu tidak langsung mmemberikan generalisasi dalam pengerjaan LKS di tahap pengumpulan data dan pemrosesan data serta tahap verifikasi. Guru juga harus memperhatikan waktu dalam membimbing sehingga waktu yang terpakai lebih efektif, dan (e) Supaya pelaksanaan pembelajaran dapat berjalan dengan maksimal, maka perlu ada persiapan yang matang baik dari peneliti, guru, maupun siswa.

\section{DAFTAR PUSTAKA}

Arikunto, S. (2007). Prosedur Penelitian Suatu Pendekatan Praktik. Jakarta: Rineka Cipta

Barlian, I. (2013). Begitu Pentingkah Strategi Belajar Mengajar Bagi Guru?. Jurnal Forum Sosial. Vol.6, No. 1, 6 halaman. (Online). Tersedia 05 April 2017.

Destiyandani. (2016). Penerapan Model Pembelajaran Numbered Heds Together (NHT) untuk Meningkatkan Hasil Belajar Siswa Kelas VIIA SMP Negeri 2 Tutang Pada Materi Segitiga. Jurnal Penelitian Pengembangan Kependidikan.Salatiga: Universitas Kristen Satya Wacana.

Gintings, A. (2008). Esensi Praktis Belajar dan Pembelajaran. Bandung: Humaniora

Hosnan, M. (2014). Pendekatan Saintifik dan Kontekstual dalam Pembelajaran Abad 21. Bogor: Ghalia Indonesia.

Josephine. (2010). Effect of Guided Discovery Learning On Students Achievement In Final Account In Financial Accounting In Colleges of Education In Edo State. Nsukka. Department of Vocational Teacher Education. University of Nigeria.

Markaban. (2008). Model Penemuan Terbimbing pada Pembelajaran Matematika SMK. Yogyakarta:PPPTK Matematika. 
Megariati. (2011). Peningkatan Hasil Belajar Matematika pada Materi Turunan Fungsi Menggunakan Teknik Probing Prompting di Kelas XI IPA 1 Sekolah Menengah Atas Negeri 2 Palembang.Jurnal Elektronik Pendidikan Matematika Universitas Sriwijaya. Vol. 5, No. 1. (Online). Tersedia: http://ejournal.unsri.ac.id/index. php/jpm/article/view/822/2355 (diakses tanggal 20 Februari 2018)

Milles, M.B., Huberman, A.M., dan Saldana, J. (2014). Qualitative Data Analysis: A Methode sourcebook edition 3. United States Of America: SAGE, Inc.

Nupita, E. (2013). Penerapan Model Pembelajaran Penemuan Terbimbing untuk Meningkatkan Hasil Belajar dan Keterampilan Pemecahan Masalah IPA pada Siswa Kelas V Sekolah Dasar. Jurnal Penelitian Pendidikan Guru Sekolah Dasar Universitas Negeri Surabaya Vol.01,No.02. (Online). Tersedia: https://scholar.google.co.id/scholar?hl=id\&q=nupita+2013\%2C+penerapan+model+ penemuan+terbimbing+untuk+meningkatkan+keterampilan+pemecahan+masalah+si swa+kelas+V+SDN+2+sidomoro+kec.+kebomas+kab.+Gresik\&btnG(diakses:tangg al 20 Februari 2018)

Nusantara, T dan Safi'i, I. (2013). Diagnosis Kesalahan Siswa pada Materi Faktorisasi Bentuk Aljabar dan Scaffoldingnya. Journal of Mathematic's Teacher Education. Vol.2,No.3,11halaman.[Online].Tersedia:http://Jurnalonline.um.ac.id/data/Artikel/arti kel29887756D901C2029476EE329D1795.pdf[12 April 2017]

Purwatiningsi, S. (2013). Penerapan Metode Penemuan Terbimbing Untuk Meningkatkan Hasil Belajar Siswa pada Materi Luas Permukaan dan Volume Balok. Jurnal Elektronik Pendidikan Matematika Tadulako (Online), Vol.1, No. 1, 11 halaman. Tersedia:http://jurnal.untad.ac.id/jurnal/index. php./JEPMT. rticle/view/3097/2170

Rahmawati, F. (2013). Pengaruh Pendekatan Pendidikan Realistik Matematika dalam MeningkatkanKemampuanKomunikasiMatematisSiswaSekolahDasar.JournalFMIPAUn ila.Vol.1,No.1,14halaman.[Online].Tersedia:http://journal.fmipa.Unila.ac.id.index.php/se mirata/article/view/882/701

Rohani, A. (2004). Pengelolaan Pengajaran. Jakarta: Rineka Cipta.

Rusmiati. (2012). Meningkatkan Hasil Belajar Siswa Kelas IV SDN 1 Inti Pembina Ampibabo Materi Menghitung Keliling Segitiga Melalui Model Pembelajaran Penemuan Terbimbing.Jurnal Kreatif Tadulako. Universitas Tadulako.

Sari, M.K. dan Jatmiko B. (2014). Upaya Meningkatkan Aktivitas dan Hasil Belajar Siswa dengan Menerapkan Model Pembelajaran Guided Discovery Pada Pokok Bahasan Elastisitas Siswa Kelas XI Di SMAN 1 Manyar. Jurnal Inovasi Pendidikan Fisika (JIPF).Vol. 03 No.02. Tersedia: http: //jurnalmahasiswa.unesa.ac.id (diakses tanggal 22 Agustus 2017)

Sari, P., Bennu, S., Mallo, B. (2014). Penerapan Metode Penemuan Terbimbing Berbantuan Alat Peraga untuk Meningkatkan Hasil Belajar Siswa Kelas VII pada Materi Luas Permukaan dan Volume Limas di SMP Negeri 19 Palu . Jurnal Elektronik Pendidikan Matematika Universitas Tadulako Vol. 2 (1), 17 halaman. [Online].Tersedi:http://jurnal.untad.ac.id/jurnal/index.php./JEPMT.rticle/view/3097/217 0 
Sunardi. (2000). Hubungan antara Usia, Tingkat Berfikir, dan Kemampuan Siswa dalam Geometri. Prosiding Seminar Nasional Matematika Jurusan Matematika ITS.

Winayawati, L., Waluya, S.B. dan Junaedi, I. (2012). Implementasi Model Pembelajaran Kooperatif dengan Strategi Think-Talk-Write Terhadap Kemampuan Menulis Rangkuman dan Pemahaman Matematis Materi Integral. Unnes Jurnal of Research

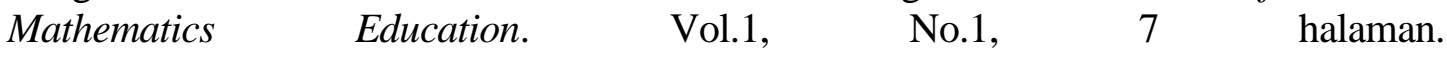
(Online).Tersedia:http://journal.unnes.ac.id/rju/indexbphp/ujrme 